\title{
PERBEDAAN PENERAPAN MODEL PEMBELAJARAN KOOPERATIF TIPE NHT DAN STAD DITINJAU DARI HASIL BELAJAR SISWA
}

\author{
Hanifah Kusumawati \\ hanifahkusumawati91@gmail.com \\ Mawardi \\ mawardi@staff.uksw.edu \\ Pendidikan Guru Sekolah Dasar - FKIP UKSW Salatiga
}

\begin{abstract}
ABSTRAK
Penelitian ini bertujuan untuk mengetahui ada tidaknya perbedaan hasil belajar matematika yang signifikan dalam penerapan model pembelajaran kooperatif tipe Numbered Head Together (NHT) dan model pembelajaran kooperatif tipe Student Teams Achivement Division (STAD) pada siswa kelas 5 SD Gugus Singoprono 1 dan 3 Simo. Subjek penelitian ini adalah siswa kelas 5B SDIT Al Falaah (SD swasta) dan SDN 02 Simo (SD Imbas) sebagai kelompok eksperimen 1, dan 5A SDIT Al Falaah (SD Swasta) dan SDN Putri (SD Imbas) sebagai kelompok eksperimen 2. Variabel dalam penelitian ini terdiri atas model NHT dan STAD sebagai variabel bebas, hasil belajar sebagai variabel terikat, dan pretest sebagai variabel kovariat. Pengumpulan data dilakukan dengan menggunakan instrumen soal tes dan lembar observasi. Teknik analisis data hasil penelitian ini menggunakan teknik deskriptif dan teknik statistik ANCOVA. Berdasarkan uji ANCOVA yang telah dilakukan terhadap skor posttest kelompok eksperimen 1 dan kelompok eksperimen 2 diperoleh hasil $\mathrm{F}$ hitung sebesar 10,303, pada taraf signifikansi/probabilitas 0,002; oleh karena nilai probabilitas tersebut $<0,05$, maka $\mathrm{H}_{0}$ ditolak dan $\mathrm{H}_{\mathrm{a}}$ diterima. Artinya terdapat perbedaan hasil belajar matematika yang signifikan pada siswa kelas 5 SD Gugus Singoprono 1 dan 3 dalam pembelajaran menggunakan model pembelajaran NHT dan STAD. Perbedaan hasil belajar Matematika yang signifikan tersebut didukung oleh perbedaan rerata dua sampel penelitian, dimana rerata hasil belajar pada penerapan model pembelajaran $N H T$ sebesar 81 , sedangkan rerata hasil belajar pada penerapan model pembelajaran STAD sebesar 74. Maknanya adalah bahwa perlakuan pembelajaran dengan model NHT memberikan dampak pada hasil belajar yang berbeda dan lebih tinggi daripada model pembelajaran STAD. Saran yang penulis ajukan berkenaan dengan hasil penelitian ini adalah guru dapat memilih model pembelajaran kooperatif tipe $N H T$ dalam pembelajaran Matematika sebagai alternatif untuk meningkatkan hasil belajar siswa.
\end{abstract}

Kata kunci: Numbered Head Together, Student Team Achievement Division, Hasil Belajar

\section{PENDAHULUAN}

\section{Latar Belakang}

Peraturan Pemerintah Republik Indonesia Nomor 19 Tahun 2005 BAB III pasal 7 ayat 3 diatur lebih lanjut dalam Lampiran Permendiknas Nomor 22 Tahun 2006 tentang Standar Isi, khususnya tentang muatan matapelajaran Matematika SD/MI. Matematika merupakan ilmu yang menjadi pondasi perkembangan teknologi modern dan mempunyai peran penting dalam memajukan daya pikir manusia. Pertumbuhan teknologi informasi dan komunikasi berlandaskan pada pertumbuhan matematika di bidang teori bilangan, aljabar, analisis, teori peluang dan matematika diskrit; oleh sebab itu, penguasaan konsep matematika harus dibangun sedini mungkin dengan cara membelajarkan matematika kepada semua peserta didik sejak 
Sekolah Dasar (SD). Menanamkan konsep matematika sejak SD dapat melatih peserta didik akan kemampuan berpikir logis, analitis, sistematis, kritis, dan kreatif, serta kemampuan bekerjasama.

Hakikat pembelajaran matematika difokuskan pada bagaimana cara menyelesaikan masalah. Dunia matematika mempunyai masalah yang cara penyelesaiannya dapat dilakukan hanya melalui satu solusi dan ada pula masalah yang solusinya bisa ditempuh melalui berbagai cara. Melihat karakter matematika yang mempunyai berbagai macam cara penyelesaian suatu masalah, maka diperlukan kemampuan memahami masalah, menyelesaikan masalah, dan menemukan solusinya; jadi pada hakikatnya pembelajaran matematika lebih ditekankan pada kemampuan berpikir.

Salah satu komponen yang turut serta memberikan pengaruh terhadap kesuksesan suatu proses pembelajaran adalah penerapan model pembelajaran yang relevan dengan bidang kajian yang dibelajarkan. Suprijono (2011: 58) menegaskan pembelajaran yang dapat memacu siswa berinteraksi dengan baik dengan siswa lainnya, dapat dilakukan guru dengan cara menerapkan model pembelajaran kooperatif.

Model pembelajaran yang berpotensi dapat diterapkan dalam membelajarkan konsepkonsep matematika secara kolaboratif adalah model NHT. Huda (2011: 203), mengemukakan diskusi kelompok dengan menggunakan model pembelajaran tipe NHT dapat memberikan peluang kepada siswa untuk saling bertukar pikiran atau pendapat dan mencari jawaban yang paling tepat secara kolaboratif. Dalam hal ini, siswa aktif dalam memecahkan soal yang diberikan guru. Model pembelajaran lain yang relevan terhadap pembelajaran matematika adalah STAD. Model pembelajaran yang dikembangkan oleh Slavin ini merupakan salah satu tipe model pembelajaran kooperatif dimana siswa dibentuk menjadi kelompok-kelompok kecil secara heterogen. Guru memaparkan materi, siswa melakukan kegiatan dalam kelompok/kuis, dan pemberian reward. Model pembelajaran ini adalah model untuk menanamkan konsep untuk berkolaborasi (Trianto, 2009: 213).

Dilihat dari sintaknya, model pembelajaran NHT \& STAD memang tidak sama, namun mempunyai satu sisi persamaan, yaitu pembelajaran dititikberatkan pada aktivitas siswa untuk berkolaborasi atau bekerja sama. Mencermati berbagai potensi kedua model pembelajaran dan hasil penelitian yang menunjukkan keampuhan kedua model secara empirik, tentu saja membingungkan guru dalam memilih model pembelajaran yang akan digunakan dalam pembelajaran karena ke dua model tersebut sama-sama mempunyai potensi dapat diterapkan dalam membelajarkan konsep-konsep matematika secara kolaboratif; oleh karena itu perlu adanya pembuktian lebih lanjut model mana yang lebih ampuh diterapkan dalam pembelajaran matematika. Potensi yang sama-sama kuat yang dimiliki model pembelajaran NHT dan STAD, menimbulkan keragu-raguan bagi pengajar dalam menerapkan model yang relevan untuk mata pelajaran matematika.

Permasalahan dalam penelitian ini berkaitan dengan ada tidaknya perbedaan hasil belajar matematika yang signifikan dalam penerapan model pembelajaran kooperatif tipe Numbered Head Together (NHT) dan model pembelajaran kooperatif tipe Student Teams Achivement Division (STAD) pada siswa kelas 5 SD Gugus Singoprono 1 dan 3 Simo.

\section{TINJAUAN PUSTAKA}

\section{Pembelajaran Matematika SD}

Matematika adalah ilmu menjadi dasar dalam menentukan nasib perkembangan teknologi di masa mendatang, karena matematika berperan sebagai suatu hal yang melatarbelakangi kemajuan daya pikir manusia. Perkembangan teknologi informasi dan 
komunikasi berlandaskan oleh perkembangan matematika di bidang teori bilangan, aljabar, analisis, teori peluang dan matematika diskrit; oleh sebab itu konsep-konsep matematika perlu ditanamkan kepada seluruh peserta didik sejak duduk di bangku SD. Kompetensi penguasaan konsep-konsep matematika tersebut diperlukan agar peserta didik mampu memperoleh, mengelola, dan memanfaatkan informasi untuk mempertahankan hidup pada perkembangan jaman yang selalu berubah dari masa ke masa dan tentu saja dengan konsekuensi persaingan semakin ketat.

Matematika merupakan ilmu universal meliputi ide, gagasan, dan konsep abstrak yang tidak bisa dilepaskan dari kehidupan manusia sehari-hari. Perkembangan matematika berbanding lurus dengan perkembangan sains dan teknologi (Wahyudi, 2012: 7). Tujuan utama pembelajaran matematika adalah meningkatkan intelektualitas peserta didik. Oleh karena penekanan pembelajaran matematika adalah meningkatkan ketajaman berpikir siswa, maka dalam pelaksanaan pembelajarannya harus direncanakan secara matang sehingga hasilnya dapat mencapai target yang diharapkan.

\section{Pembelajaran Kooperatif}

Menurut Slavin (2011) pembelajaran kooperatif adalah cara siswa bekerjasama dalam tim dengan anggota yang heterogen. Menurut Trianto, (2009: 56) melalui pembelajaran kooperatif merupakan langkah untuk mempermudah siswa dalam memahami konsep. Melalui pembelajaran kooperatif siswa akan berdiskusi saling membantu dalam memahami konsep sehingga tercapailah suatu ketuntasan belajar. Menurut Depdiknas, melalui pembelajaran kooperatif siswa mampu meningkatkan kemampuan akademik, menerima segala bentuk perbedaan teman-temannya, mempunyai jiwa sosial yang tinggi. Dari tiga pendapat mengenai tujuan pembelajaran kooperatif, dapat dirumuskan bahwa pada hakikatnya pembelajaran kooperatif bertujuan meningkatkan kemampuan akademik siswa, menumbuhkan rasa toleransi, dan meningkatkan keterampilan sosial.

\section{Model Pembelajaran Kooperatif Tipe Numbered Heads Together (NHT)}

Numbered Heads Together (NHT) atau penomoran berpikir bersama dikembangkan oleh Spencer Kagan (1992). Model pembelajaran NHT memberi kesempatan siswa saling bertukar gagasan dan menentukan jawaban yang paling tepat (Miftahul Huda, 2011: 138). Ridwan, (2015: 44) mengungkapkan NHT merupakan model pembelajaran kooperatif yang menuntut siswa untuk berpikir bersama kelompoknya. Setiap anggota kelompok diberi nomor dan berkesempatan menjawab pertanyaan dari guru.

Unsur-unsur yang yang terkandung dalam model NHT adalah sebagai berikut: 1) Sintagmatis. Menurut Trianto, (2009: 82) penerapan model NHT dilakukan melalui enam fase: a) Fase 1: Penomoran. b) Fase 2: Pengajuan pertanyaan. c) Fase 3: Berpikir bersama. d) Fase 4: Menjawab pertanyaan. Fase 5: Kesimpulan. Fase 6: Reward. 2) Prinsip Reaksi, menggambarkan pola tingkah laku guru dalam memperlakukan siswa ketika belajar. Peran guru dalam pembelajaran kooperatif tipe $N H T$ adalah sebagai fasilitator yang terlibat langsung dalam pembelajaran. Guru juga berperan sebagai pembimbing setiap kelompok dengan menciptakan suasana yang hangat dan menyenangkan. Guru menjelaskan tentang tata cara/aturan pembelajaran yang akan berlangsung dengan jelas sehingga semua siswa dapat memahami dengan baik. Guru memfasilitasi dan mengarahkan siswa dalam membentuk kelompok dengan transisi yang efisien. Setelah terbentuk kelompok-kelompok, guru memberikan arahan tentang cara diskusi kelompok; dimana guru mengajukan pertanyaan kepada siswa yang mempunyai kepala bernomor sama secara acak kemudian guru mengamati siswa dalam diskusi. Setelah 
siswa memaparkan jawabannya, guru melakukan pemantapan materi dan klarifikasi apabila siswa mengalami miskonsepsi.

Unsur ke-3, Sistem Sosial, yaitu norma yang terdapat dalam model ini berlandaskan pada proses demokrasi dan keputusan kelompok. Guru tidak sepenuhnya menjadi pusat perhatian, namun ada kalanya perhatian tersebut tertuju pada siswa. Sistem sosial dalam pembelajaran ini berupa sikap saling membantu antarteman dalam kelompok. Siswa saling bahu-membahu dalam mencari jawaban yang paling tepat atas pertanyaan yang diterima. Ketika berlangsungnya diskusi untuk mencari jawaban yang tepat, setiap anggota kelompok pasti mempunyai jawaban atau gagasan yang berbeda-beda. Dalam hal ini tentu saja harus ada pendapat yang diterima dan ditolak. Disinilah siswa akan belajar saling menghargai pendapat yang dikemukakan oleh teman. Selain itu, ketika jawaban dari semua kelompok dibacakan dan dikoreksi, akan terlihat kelompok mana yang mempunyai prestasi tertinggi dan terendah. Kelompok yang mempunyai prestasi rendah, akan belajar menerima kekalahan kelompok sendiri dan menghargai kemenangan kelompok lain.

Unsur ke-4, Daya Dukung, dalam pembelajaran kooperatif $N H T$ salah satunya adalah kondisi lingkungan fisik sesuai kebutuhan siswa dalam pembelajaran seperti kebersihan dan kenyamanan ruang kelas, ketersediaan sarana dan prasarana yang memadai untuk menunjang proses pembelajaran yang berupa meja, kursi, papan tulis, dll. Selain itu, guru harus mempersiapkan bahan ajar yang digunakan yaitu berupa materi pecahan untuk siswa lengkap dengan Lembar Kerja Siswa (LKS) atau berupa pertanyaan yang siap diajukan kepada siswa dan sumber belajar (buku dan lingkungan sekitar siswa) yang berkaitan dengan materi pecahan. Tidak lupa guru harus menyusun Rencana Pelaksanaan Pembelajaran (RPP) sebelum melaksanakan kegiatan pembelajaran.

Unsur ke-5, Dampak Instruksional dan Dampak Pengiring. Dampak instruksional merupakan hasil belajar yang harus dikuasai siswa berupa kemampuan-kemampuan siswa setelah menerima atau menyelesaikan pengalaman belajarnya. Dampak instruksional setelah siswa mengikuti pembelajaran matematika dengan menggunakan model pembelajaran kooperatif tipe $N H T$ yaitu proses pembentukan dan pengelolaan kelompok dapat dilakukan secara efisien sesuai minat siswa namun masih dalam kontrol guru; sehingga proses pembelajaran secara berkelompok dapat berjalan dengan baik dan mencapai tujuan yang diharapkan. Melalui model pembelajaran kooperatif tipe $N H T$ ini, diharapkan dapat membiasakan siswa untuk membangun pengetahuannya melalui diskusi kelompok, sehingga siswa akan lebih termotivasi untuk belajar. Melalui proses kerjasama dalam kelompok, siswa berlatih untuk disiplin dan tanggung jawab dari masing-masing anggota kelompok, sehingga semua anggota kelompok dapat berpartisipasi aktif dalam diskusi.

\section{Model Pembelajaran Kooperatif Tipe STAD}

Menurut Slavin, (2011: 21) STAD merupakan penempatan siswa ke dalam tim-tim yang berbeda jenis kelamin, tingkat kinerja, dan suku bangsa. Penerapan model STAD ini, diawali dengan penyampaian tujuan pembelajaran, penyajian materi oleh guru, kegiatan menguasai materi bersama kelompok, kuis, dan diakhiri dengan penghargaan kelompok (Trianto, 2009: 68). Kokom Komalasari, (2010: 63) mendefinisikan STAD sebagai sebuah model pembelajaran dengan cara mengelompokkan siswa secara heterogen, kemudian siswa yang pandai menjelaskan pada anggota lain sampai mengerti.

Komponen-komponen dari model pembelajaran STAD yaitu sebagai berikut: 1) Sintagmatis. Slavin (1990) membagi fase-fase yang harus ditempuh dalam menerapkan model kooperatif tipe STAD. Fase-fase tersebut adalah Fase 1 (Penyajian informasi), Fase 2 (Membagi siswa ke dalam tim-tim secara heterogen), Fase 3 (Kerja tim), Fase 4 Kuis/Evaluasi, 
Fase 5 (reward). 2) Prinsip Reaksi, menggambarkan perilaku guru terhadap siswa ketika berlangsungnya proses pembelajaran. Pada pembelajaran kooperatif tipe STAD adalah guru bertindak sebagai fasilitator; menjelaskan aturan yang berlaku dalam pembelajaran dan mengelompokkan siswa berdasarkan tingkat prestasi, jenis kelamin, dan ras. Lebih dari seorang fasilitator, guru juga berperan sebagai konselor akademik bagi setiap kelompok sehingga terjalin hubungan yang akrab dan hangat antara siswa dan guru. Ketika proses diskusi berjalan, guru berkeliling memantau aktivitas siswa dalam kelompok, juga memberikan bimbingan jika diperlukan. Guru mengecek kemampuan siswa dalam kelompok dengan cara memberikan pertanyaan/soal. Guru melakukan klarifikasi atas hasil diskusi/kerja tim. Dalam rangka menguasai hasil belajar masing-masing siswa, guru memberikan kuis secara individual.

Unsur ke-3, Sistem Sosial. Sistem sosial yang terdapat dalam model ini adalah kerjasama dalam kelompok. Siswa saling membantu dalam menguasai materi yang diberikan guru. Perbedaan tingkat intelektual, jenis kelamin, dan ras sangat berpengaruh dalam melatih siswa menerima perbedaan di lingkungan sekitar. Terbentuk rasa tanggungjawab bersama-sama untuk memperoleh prestasi kelompok terbaik. Ketika siswa mulai bingung dalam berdiskusi, guru akan bersikap sebagai teman sebaya yang sedang memberikan tutor kepada anggotanya. 4) Daya Dukung, ketersediaan bahan ajar (RPP, materi, maupun soal latihan), lingkungan fisik/ruang kelas yang bersih dan nyaman, ketersediaan sarana dan prasarana berupa meja, kursi, papan tulis, dll. Selain itu, guru harus mempersiapkan instrumen kuis individual.

Unsur ke-5, Dampak Instruksional dan Dampak Pengiring. Dampak instruksional yang ditimbulkan dari pembelajaran matematika dengan materi pecahan melalui model STAD adalah kemampuan menentukan pecahan-pecahan yang senilai dan menyederhanakan pecahan. Dampak pengiring adalah kemampuan lain yang muncul dari suasana pembelajaran yang dialami siswa diluar arahan dari guru. Dampak pengiring yang timbul dari pembelajaran matematika dengan menggunakan model pembelajaran kooperatif tipe STAD adalah siswa mampu berdiskusi bersama kelompoknya yang heterogen, siswa yang mempunyai kemampuan akademik yang tinggi akan membantu (menjelaskan materi) kepada anggota yang mempunyai kemampuan akademik rendah. Model pembelajaran ini akan memacu siswa agar saling mendorong dan membantu satu sama lain untuk menguasai keterampilan yang diajarkan guru. Adanya rasa tanggung jawab atas tugas yang diberikan kepada kelompoknya.

Secara khusus, dampak pengiring yang akan didapatkan siswa melalui pembelajaran menggunakan model STAD adalah melatih ketekunan, konsentrasi, dan keaktifan siswa, menumbuhkan sikap disiplin, toleransi, kerjasama, tanggung jawab. Disamping itu, siswa akan berpikir kritis dan percaya diri untuk mengemukakan pendapat ketika berdiskusi maupun presentasi.

Berbagai penelitian tentang keampuhan model pembelajaran NHT dan STAD dilaporkan oleh berbagai peneliti, diantaranya penelitian yang dilakukan oleh Wirani, W. dan Bondan, D. (2012), menemukan bahwa model pembelajaran kooperatif tipe NHT lebih baik dibanding tipe $S T A D$ dalam meningkatkan kemampuan komunikasi matematis. Mendukung penelitian Wirani, W. dan Bondan, D. (2012), Rofiq Setyawan (2008), telah membuktikan model pembelajaran NHT lebih baik dibandingkan dengan model ceramah. Begitu pula hasil penelitian yang dilakukan oleh Farida Esty Purwasih (2014), yang menunjukkan bahwa penggunaan model pembelajaran NHT memberikan pengaruh yang signifikan dibandingkan dengan model STAD terhadap hasil belajar siswa.

Desi Imanuni (2013), juga telah berhasil membuktikan bahwa terdapat perbedaan hasil belajar yang signifikan dalam penerapan model pembelajaran $N H T$ dan $S T A D$, rata-rata nilai siswa dengan menggunakan model $N H T$ lebih tinggi dibandingkan nilai rata-rata siswa dengan menggunakan model STAD. Senada dengan hasil penelitian Desi Imanuni, Rois Anisatul 
Azizah (2011), memperoleh hasil dalam penelitiannya yaitu terdapat perbedaan yang signifikan terhadap penerapan model $N H T$ dan $S T A D$, dimana nilai rata-rata siswa yang diajar dengan menggunakan model NHT lebih tinggi dibandingkan nilai rata-rata siswa yang diajar dengan menggunakan model pembelajaran STAD.

Penelitian yang dilakukan oleh Misbahul Ibad (2013), juga telah membuktikan bahwa model pembelajaran NHT lebih baik dibandingkan model pembelajaran STAD. Tidak berbeda dengan hasil penelitian Misbahul Ibad, Rossy Noviasari (2013) telah membuktikan bahwa model pembelajaran NHT memberikan pengaruh yang lebih besar terhadap hasil belajar siswa dibandingkan dengan model pembelajaran STAD.

Di sisi lain, penelitian tentang keampuhan model pembelajaran kooperatif tipe STAD juga dilaporkan oleh beberapa peneliti. Kuswoyo, A. (2009) berhasil membuktikan bahwa model pembelajaran kooperatif tipe $S T A D$ lebih efektif dibanding model pembelajaran kooperatif tipe $N H T$ terhadap kemampuan pemecahan masalah matematika. Hasil penelitian Kuswoyo, A. (2009), juga didukung oleh hasil penelitian Magor, Y., C. (2010) bahwa hasil belajar siswa yang diajarkan dengan pembelajaran kooperatif STAD lebih baik dibandingkan dengan siswa yang diajarkan dengan pembelajaran kooperatif NHT. Saraswati, I., D. (2010), berhasil membuktikan model pembelajaran kooperatif tipe STAD dapat meningkatkan hasil belajar siswa.

Erik Danuharja (2010) juga memperoleh hasil penelitian yang menunjukkan perbedaan yang signifikan dalam penerapan model STAD dan NHT, dimana nilai kelas menggunakan model STAD lebih tinggi dibandingkan nilai kelas menggunakan model $N H T$. Penelitian Ropiatun Nafisah (2011), yang menunjukkan bahwa model pembelajaran STAD lebih efektif meningkatkan keaktifan siswa dibandingkan dengan model pembelajaran NHT. Teresia Ari Dwi Utami (2011), hasil penelitiannya menunjukkan bahwa pembelajaran menggunakan model pembelajaran kooperatif $S T A D$ lebih baik dibandingkan model pembelajaran kooperatif tipe NHT.

Hasil yang berbeda didapatkan oleh Yuziana, D. (2011), yaitu prestasi belajar siswa yang diajar dengan model pembelajaran kooperatif tipe $N H T$ sama dengan prestasi belajar siswa yang diajar dengan manggunakan model pembelajaran kooperatif tipe STAD. Penelitian yang dilakukan oleh Ardian, (2014) yang menunjukkan bahwa hasil belajar siswa yang diperoleh melalui model pembelajaran kooperatif tipe $N H T$ dan model kooperatif tipe $S T A D$ tidak terdapat perbedaan yang signifikan.

Rodi, Tsamarul Hizbi, dan Laxmi Zahara (2011) juga membuktikan bahwa penerapan model pembelajaran kooperatif $N H T$ dan STAD tidak ada perbedaan pengaruh yang signifikan terhadap prestasi belajar siswa. I. G. M. R. Aryana (2015), juga memberikan hasil penelitian yang berbeda dengan hasil penelitian ini, dimana tidak ada perbedaan hasil belajar yang signifikan dalam penerapan model pembelajaran NHT dan STAD. Begitu pula Dalila (2010), yang memperoleh hasil melalui penelitiannya menunjukkan tidak ada perbedaan yang signifikan dalam penerapan model STAD dan NHT.

\section{METODE}

Penelitian ini menggunakan jenis penelitian eksperimen semu atau dikenal dengan eksperimen kuasi. Sugiyono, (2014: 116) berpandangan eksperimen kuasi dapat digunakan apabila mengalami kesulitan dalam mendapatkan kelompok kontrol yang benar-benar dapat mengontrol variabel-variabel luar yang mempengaruhinya. Desain yang digunakan adalah Nonequivalent Control Group Design. Terdapat dua kelompok eksperimen, yaitu kelompok eksperimen 1 dan kelompok eksperimen 2 (gambar 1) yang dipilih tidak secara random, tetapi matching only (Gay, 1987: 277). 


\begin{tabular}{|c|c|c|c|}
\hline Kelompok & $\begin{array}{c}\text { Sebelum } \\
\text { Perlakuan }\end{array}$ & Perlakuan & $\begin{array}{c}\text { Sesudah } \\
\text { Perlakuan }\end{array}$ \\
\hline Kelompok Eksperimen 1 & $\mathrm{O}_{1}$ & $\mathrm{X}_{1}$ & $\mathrm{O}_{2}$ \\
\hline Kelompok Eksperimen 2 & $\mathrm{O}_{3}$ & $\mathrm{X}_{2}$ & $\mathrm{O}_{4}$ \\
\hline
\end{tabular}

Gambar 1 Nonequivalent Control Group Design

Penelitian dilakukan di SD Gugus Singoprono 1 dan Singoprono 3 yang terletak di wilayah Kecamatan Simo, Kabupaten Boyolali, Jawa Tengah. Dalam penelitian ini terdapat tiga variabel, yaitu variabel bebas $\left(\mathrm{X}_{1}\right)$, variabel terikat $(\mathrm{Y})$, dan variabel kovariat $\left(\mathrm{X}_{2}\right)$. Variabel bebas (independent) merupakan tindakan yang mempunyai pengaruh terhadap variabel terikat (dependent). Variabel kovariat adalah variabel yang digunakan untuk mengontrol/memfilter semua perlakuan tidak terkontrol terhadap variabel terikat.Dalam penelitian ini digunakan pretest sebagai variabel kovariat $\left(\mathrm{X}_{2}\right)$. Penerapan model pembelajaran $N H T$ dan STAD merupakan variabel bebas $\left(\mathrm{X}_{1}\right)$, sedangkan hasil belajar matematika merupakan variabel terikat (Y).

Populasi dalam penelitian ini meliputi siswa kelas 5 SD Gugus Singoprono 1 dan 3, Simo, Boyolali sejumlah 323 orang. Sampel yang diambil adalah kelompok eksperimen 1 (45 siswa) dan eksperimen 2 (45 siswa) yang tersebar di SD Negeri 02 Simo, SD Al Falaah dan SD Negeri Putri. Instrumen pengumpulan data pada penelitian ini menggunakan instrumen tes sebanyak 20 soal, yang telah diuji reliabilitasnya sebesar 0.82 . Angka koefisien reliabilitas Alpha ini berada pada kategori reliabel. Hasil uji validitas item ke-20 soal tersebut bergerak antara $0,30 \mathrm{sd} 0,538$.

Teknik analisis data hasil penelitian ini dianalisis dengan teknik deskriptif dan teknik statistik inferensial ANCOVA. Teknik statistik ANCOVA dilakukan jika memenuhi uji prasyarat: a) uji normalitas, b) uji homogenitas, dan c) uji linieritas data. Analisis of Covariance dapat digunakan untuk membandingkan rerata prestasi belajar antar kelompok dengan mengontrol pengaruh variabel kovariat. Pada analisis kovariansi, koefisien korelasi lebih dari 0.60 sudah dianggap cukup tinggi (Budiyono, 2011: 299 - 300).

\section{HASIL PENELITIAN DAN PEMBAHASAN}

\section{Hasil Uji ANCOVA Rerata Hasil Belajar}

Uji normalitas data dilakukan untuk mengetahui data berasal dari distribusi normal atau tidak. Pengujian normalitas data dilakukan dengan bantuan uji Kolmogorov-Smirnov, dengan dasar pengambilan keputusan; jika nilai signifikansi/probabilitas $<0,05$, maka data berdistribusi tidak normal. Apabila nilai signifikansi/probabilitas $>0,05$, maka data berdistribusi normal. Berdasarkan hasil uji normalitas diperoleh nilai Asymp. Sig. (2-tailed) uji Kolmogorov-Smirnov $Z$ hasil pretest-posttest kelompok eksperimen 1 adalah 0,431 dan 0,511. Sedangkan hasil pretest-posttest kelompok eksperimen 2 adalah 0,617 dan 0,726. Bila dirumuskan sebuah hipotesis $\mathrm{H}_{0}$ adalah sebuah sampel yang berasal dari populasi berdistribusi normal dan $\mathrm{H}_{\mathrm{a}}$ adalah sampel yang tidak berasal dari populasi berdistribusi normal, maka dapat diputuskan jika probabilitas < nilai $\alpha(0,05) \mathrm{H}_{0}$ ditolak, jika sebaliknya maka $\mathrm{H}_{0}$ diterima. Oleh karena nilai signifikansi/probabilitas Asymp. Sig. (2-tailed) data-data tersebut berturut-turut 0,431; 0,511;

0,617 dan 0,726>0,05 maka $\mathrm{H}_{0}$ diterima, artinya dapat disimpulkan bahwa persebaran data hasil pretest-posttest kelompok eksperimen 1 dan kelompok eksperimen 2 tersebut berasal dari populasi yang berdistribusi normal. 
Berdasarkan hasil Test of Homogeneity of Variances signifikansi/probabilitas nilai pretest menunjukkan angka 0,337 . Bila dirumuskan sebuah hipotesis $\mathrm{H}_{0}$ adalah variansi data pada tiap kelompok sama (homogen) dan $\mathrm{H}_{\mathrm{a}}$ adalah variansi data pada tiap kelompok tidak sama (tidak homogen), maka dapat diputuskan jika probabilitas < nilai $\alpha(0,05) \mathrm{H}_{0}$ ditolak, jika sebaliknya maka $\mathrm{H}_{0}$ diterima. Oleh karena nilai signifikansi/probabilitas data pretes dan postes kedua kelompok adalah sebesar 0,337 dan 0,791>0,05 maka $\mathrm{H}_{0}$ diterima. Artinya dapat dikatakan bahwa skor pretest kelompok eksperimen 1 dan kelompok eksperimen 2 adalah homogen. Skor signifikansi/probabilitas posttest kelompok eksperimen 1 dan kelompok eksperimen 2 adalah 0,791, dengan demikian dapat dikatakan bahwa nilai posttest kelompok eksperimen 1 dan kelompok eksperimen 2 adalah homogen. Melihat skor signifikansi/probabilitas pretest-posttest kelompok eksperimen 1 dan kelompok eksperimen 2, dapat disimpulkan bahwa data skor pretest-posttest kelompok eksperimen 1 dan kelompok eksperimen 2 memiliki varian data yang homogen atau sama.

Setelah uji normalitas dan homogenitas terpenuhi dilanjutkan uji homogenitas koefisien regresi linier untuk mengetahui kehomogenitasan koefisien regresi $\mathrm{X}_{2}$ (variabel kovarianpretest) dengan hasil belajar (Y). Paramenter yang digunakan untuk menentukan homogenitas koefisien regresi adalah nilai koefisien beta (B) pada tabel output parameter estimates dan nilai t serta probabilitasnya. Syarat yang lain adalah bahwa nilai beta (B) haruslah lebih besar sama dengan 0,60 (Budiyono, 2009: 300). Jika probabilitas lebih kecil dari 0,05 maka koefisien regresi linier kedua sampel homogen. Berdasarkan uji koefisien regresi linier pada parameter estimates dapat dilihat nilai beta (B) sebesar 0,901 lebih besar dari 0,60, nilai t sebesar 17,049 berada pada signifikasni/probabilitas 0,000 , maka koefisien regresi linier kedua sampel homogen dan model ANCOVA dapat digunakan.

Berdasarkan hasil uji normalitas yang menunjukkan data berdistribusi normal, uji homogenitas yang menunjukkan varian data homogen, dan uji homogenitas koefisien regresi linier yang menunjukkan kedua model beregresi linier maka dapat dikatakan uji prasyarat telah terpenuhi. Uji analisis berikutnya adalah ANCOVA (lihat tabel 1).

Tabel 1

Ringkasan Hasil Uji ANCOVA

Dependent Variable: Hasil Belajar

\begin{tabular}{llllll}
\hline \multicolumn{7}{c}{ Tests of Between-Subjects Effects } \\
\hline \multicolumn{1}{c}{ Source } & $\begin{array}{l}\text { Type III Sum } \\
\text { of Squares }\end{array}$ & df & Mean Square & F & Sig. \\
\hline Corrected Model & $18850,541^{\mathrm{a}}$ & 2 & 9425,271 & 154,368 &, 000 \\
\hline Intercept & 1030,935 & 1 & 1030,935 & 16,885 &, 000 \\
\hline Pretes & 17748,041 & 1 & 17748,041 & 290,680 &, 000 \\
\hline Model Pembelajaran & 629,095 & 1 & 629,095 & 10,303 &, 002 \\
\hline Error & 5311,959 & 87 & 61,057 & & \\
\hline Total & 564725,000 & 90 & & & \\
\hline Corrected Total & 24162,500 & 89 & & & \\
\hline
\end{tabular}

Ringkasan uji ANCOVA seperti tertera dalam tabel 1 tersebut memberikan informasi besarnya nilai $\mathrm{F}$ dan sigifikansinya. Pada sumber varian corrected model, nampak bahwa $\mathrm{F}$ hitung sebesar 154,368 dengan taraf signifikansi hitung 0,000. Oleh karena $0,000<\alpha=0,050$, maka dampak variabel independen secara simultan terhadap variabel dependen signifikan. 
Maknanya bahwa model pembelajaran NHT dan pretest secara simultan memiliki dampak yang berbeda secara signifikan terhadap hasil belajar siswa, dibandingkan dengan model pembelajaran STAD.

Pada varian intercept nampak bahwa $\mathrm{F}$ hitung sebesar 16,885 dengan taraf signifikansi hitung 0,000 . Oleh karena $0,000<\alpha=0,050$, maka nilai intercept signifikan. Nilai intercept merupakan besaran konstanta perubahan nilai variabel dependen sebesar nilai tersebut meskipun tanpa dipengaruhi keberadaan kovariat dan variabel independen. Pada kovarian pretest, diperoleh data F hitung 290,680, dengan taraf signifikansi 0,000. Oleh karena 0,000 $<\alpha=0,050$, maka nilai dampak kovariat signifikan. Artinya ada perbedaan pengaruh pretest terhadap hasil belajar siswa.

Pada varian model pembelajaran, diperoleh nilai $\mathrm{F}$ hitung sebesar 10,303 dengan signifikansi hitung 0,002 . Oleh karena nilai 0,002 lebih kecil dari $\alpha=0,050$, maka nilai $F$ signifikan. Artinya bahwa dampak pembelajaran $N H T$ berbeda secara signifikan dengan STAD.

\section{Hasil Uji Hipotesis}

Hipotesis yang diuji pada penelitian ini adalah:

$\mathrm{H}_{0}: 1=2$ Tidak terdapat perbedaan hasil belajar matematika yang signifikan pada siswa kelas 5 SD Gugus Singoprono 1 dan 3 dalam pembelajaran menggunakan model pembelajaran NHT dan STAD.

$\mathrm{H}_{\mathrm{a}}: 1 \neq 2$ Terdapat perbedaan hasil belajar matematika yang signifikan pada siswa kelas 5 SD Gugus Singoprono 1 dan 3 dalam pembelajaran menggunakan model pembelajaran NHT dan STAD.

Berdasarkan uji ANCOVA yang telah dilakukan terhadap nilai posttest kelompok eksperimen 1 dan kelompok eksperimen 2, diperoleh nilai probabilitas 0,002; oleh karena $0,0002<0,05$ maka $\mathrm{H}_{0}$ ditolak dan $\mathrm{H}_{\mathrm{a}}$ diterima. Artinya terdapat perbedaan hasil belajar matematika yang signifikan pada siswa kelas 5 SD Gugus Singoprono 1 dan 3 dalam pembelajaran menggunakan model pembelajaran NHT dan STAD.

\section{Pembahasan Hasil Penelitian}

Signifikansi perlakukan dimana terdapat perbedaan hasil belajar matematika yang signifikan pada siswa kelas 5 SD Gugus Singoprono 1 dan 3 dalam pembelajaran menggunakan model pembelajaran NHT dan STAD didukung oleh rerata dari dua sampel dimana rerata hasil belajar pada penerapan model pembelajaran $N H T$ sebesar 81, sedangkan rerata hasil belajar pada penerapan model pembelajaran sebesar 74. Maknanya adalah bahwa perbedaan rerata hasil belajar dan signifikansi perlakuan membuktikan bahwa model pembelajaran NHT memberikan dampak berbeda dan lebih tinggi daripada model pembelajaran STAD.

Keampuhan model pembelajaran NHT memberikan dampak hasil belajar lebih tinggi dibandingkan dengan menggunakan model pembelajaran STAD. Temuan ini sesuai dengan teori yang dikemukakan oleh Trianto (2009: 82), proses pembelajaran yang menggunakan model kooperatif $N H T$ melibatkan banyak anggota kelompokuntukmemahami materi yang dipelajari dan mengecek tingkat pemahaman siswa terhadap materi tersebut sehingga dapat meningkatkan hasil belajar siswa.

Hasil penelitian ini sejalan dengan penelitian yang dilakukan oleh Wirani, W. dan Bondan, D. (2012), bahwa model pembelajaran kooperatif tipe NHT lebih baik dibanding tipe STAD dalam meningkatkan kemampuan komunikasi matematis siswa. Mendukung penelitian Wirani, W. dan Bondan, D. (2012), Rofiq Setyawan (2008), telah membuktikan model pembelajaran NHT lebih baik dibandingkan dengan model ceramah. Begitu pula hasil penelitian yang dilakukan oleh Farida Esty Purwasih (2014), yang menunjukkan bahwa penggunaan 
model pembelajaran $N H T$ memberikan pengaruh yang signifikan dibandingkan dengan model STAD terhadap hasil belajar siswa.

Tidak hanya Wirani, W. dan Bondan, D., Rofiq Setyawan, \& Farida Esti Purwasih, keampuhan model pembelajaran NHT juga telah dibuktikan oleh Sadiman (2015), hasil studi komparasinya menunjukkan model $N H T$ lebih efektif diterapkan pembelajaran matematika dibandingkan model STAD. Nurhalimah, Titi (2008) juga telah membuktikan bahwa model NHT lebih baik daripada model STAD pada pembelajaran matematika. Begitu pula dengan penelitian Normansyah, Wahyu (2013), hasil penelitiannya menunjukkan hasil belajar matematika siswa yang diajar menggunakan model kooperatif tipe $N H T$ lebih baik daripada prestasi siswa yang diajar menggunakan model STAD.

Desi Imanuni (2013), juga telah berhasil membuktikan bahwa terdapat perbedaan hasil belajar yang signifikan dalam penerapan model pembelajaran $N H T$ dan $S T A D$, rata-rata nilai siswa dengan menggunakan model $N H T$ lebih tinggi dibandingkan nilai rata-rata siswa dengan menggunakan model STAD. Senada dengan hasil penelitian Desi Imanuni, Rois Anisatul Azizah (2011), memperoleh hasil dalam penelitiannya yaitu terdapat perbedaan yang signifikan terhadap penerapan model $N H T$ dan $S T A D$, dimana nilai rata-rata siswa yang diajar dengan menggunakan model NHT lebih tinggi dibandingkan nilai rata-rata siswa yang diajar dengan menggunakan model pembelajaran STAD.

Penelitian yang dilakukan oleh Misbahul Ibad (2013), juga telah membuktikan bahwa model pembelajaran NHT lebih baik dibandingkan model pembelajaran STAD. Tidak berbeda dengan hasil penelitian Misbahul Ibad, Rossy Noviasari (2013) telah membuktikan bahwa model pembelajaran NHT memberikan pengaruh yang lebih besar terhadap hasil belajar siswa dibandingkan dengan model pembelajaran STAD.

Selain mendukung hasil penelitian yang dilakukan oleh Wirani, W. dan Bondan, D., Rofiq Setyawan, Farida Esty Purwasih, Sadiman, Wahyu Normansyah, Titi Nurhalimah, Desi Imanuni, Rois Anisatul Azizah, Misbahul Ibad, dan Rossy Noviasari, hasil penelitian ini bertentangan dengan hasil penelitian yang dilakukan oleh Kuswoyo, A. (2009), yang menunjukkan bahwa model pembelajaran kooperatif tipe STAD lebih efektif dibanding model pembelajaran kooperatif tipe $N H T$ terhadap kemampuan pemecahan masalah matematika. Selain bertentangan dengan hasil penelitian yang dilakukan oleh Kuswoyo, A. (2009), hasil penelitian ini juga bertentangan dengan hasil penelitian Magor, Y., C. (2010) yang menunjukkan bahwa hasil belajar siswa yang diajarkan dengan pembelajaran kooperatif STAD lebih baik dibandingkan dengan siswa yang diajarkan dengan pembelajaran kooperatif $N H T$.

Erik Danuharja (2010) juga memperoleh hasil penelitian yang menunjukkan perbedaan yang signifikan dalam penerapan model STAD dan NHT, dimana hasil belajar siswa menggunakan model STAD lebih tinggi dibandingkan nilai siswa menggunakan model $N H T$. Begitu pula dengan hasil penelitian yang dilakukan oleh Saraswati, I., D. (2010), yang menunjukkan bahwa model pembelajaran kooperatif tipe STAD dapat meningkatkan hasil belajar siswa, juga terbantahkan oleh hasil penelitian ini.

Penelitian yang juga bertentangan dengan hasil penelitian ini adalah penelitian Ropiatun Nafisah (2011), yang menunjukkan bahwa model pembelajaran STAD lebih efektif meningkatkan keaktifan siswa dibandingkan dengan model pembelajaran NHT. Hasil penelitian ini juga berbeda dengan hasil penelitian yang dilakukan oleh Jonet Prasetya (2013), yang memperoleh nilai rata-rata hasil belajar matematika siswa yang diajar menggunakan Model Pembelajaran Kooperatif Tipe STAD lebih baik, daripada siswa yang diajar dengan menggunakan Model Pembelajaran Kooperatif Tipe NHT. Hasil penelitian yang tidak sajalan dengan hasil penelitian ini, juga berlaku pada hasil penelitian yang dilakukan oleh Teresia Ari 
Dwi Utami (2011), yang menunjukkan bahwa pembelajaran menggunakan model pembelajaran kooperatif STAD lebih baik dibandingkan model pembelajaran kooperatif tipe $N H T$.

Hasil penelitian ini juga berbeda dengan hasil penelitian yang dilakukan oleh Ardian, (2014) yang menunjukkan bahwa hasil belajar siswa yang diperoleh melalui model pembelajaran kooperatif tipe Numbered Head Together (NHT) dan model kooperatif tipe Student Team Achievement Division (STAD) tidak terdapat perbedaan yang signifikan. Hasil penelitian yang dilakukan oleh Rodi, Tsamarul Hizbi, dan Laxmi Zahara (2011) juga berbeda dengan hasil penelitian ini, dimana penerapan model pembelajaran kooperatif $N H T$ dan STAD tidak ada perbedaan pengaruh yang signifikan tehadap prestasi belajar siswa. I. G. M. R. Aryana (2015), juga memberikan hasil penelitian yang berbeda dengan hasil penelitian ini, dimana tidak ada perbedaan hasil belajar yang signifikan dalam penerapan model pembelajaran NHT dan STAD. Begitu pula Dalila (2010), yang memperoleh hasil melalui penelitiannya menunjukkan tidak ada perbedaan yang signifikan dalam penerapan model STAD dan NHT.

Hasil penelitian ini dapat memperkuat hasil penelitian mengenai keampuhan model pembelajaran NHT seperti yang telah dilakukan oleh Sukarno (2014), simpulan hasil penelitiannya adalah model pembelajaran kooperatif $N H T$ dapat meningkatkan prestasi belajar siswa. Rika Pristianti Setianingrum (2013), simpulan hasil penelitiannya adalah penggunaan model pembelajaran NHT mempunyai pengaruh terhadap hasil belajar siswa.

Keampuhan model pembelajaran NHT dimungkinkan karena dilaksanakannya sintak/langkah-langkah NHT khususnya pada sintak kedua, ketiga, dan keempat. Adapun isi ketiga sintak tersebut adalah pemberian pertanyaan dari guru kepada siswa, kemudian siswa mencari jawaban melalui diskusi, dan siswa memberikan jawaban secara terbuka sehingga seluruh siswa dapat mengetahui mana jawaban yang tepat dan bagaimana penyelesaiannya.

Selain itu, terdapat kelebihan model pembelajaran NHT seperti yang dikemukakan oleh Miftahul Huda, (2011: 139) bahwa model NHT memudahkan siswa dalam membagi tugas anggota kelompok, memudahkan siswa melaksanakan tanggugjawab secara individu sebagai anggota kelompok, memudahkan siswa dalam mencari jawaban yang tepat, selain itu dapat diterapkan untuk semua mata pelajaran dan tingkatan kelas. Lebih dari itu, ketika siswa sedang menyatukan kepala untuk berpikir, siswa akan berlatih mengemukakan pendapat, berlatih menghargai pendapat orang lain, belajar menerima ketika pendapatnya belum diterima. Siswa berlatih menjadi tutor sebaya kepada anggota yang belum paham. Meskipun demikian, disisi lain tetap terdapat kelemahan pada model $N H T$ yaitu siswa yang kurang pandai cenderung tidak mau berusaha/berpendapat dan hanya mengandalkan kepada siswa yang pandai.

Keberhasilan model pembelajaran $N H T$ sejalan dengan kerangka pikir yang telah disusun pada BAB II. Melalui pembelajaran dengan menggunakan model NHT pada mata pelajaran matematika, siswa dapat menjumlahkan dan mengurangkan pecahan desimal, campuran, maupun pecahan biasa. Adapun langkah-langkah yang ditempuh dalam proses pembelajaran menggunakan model $N H T$ terdiri atas 5 langkah.

Langkah pertama yang dilakukan pada pembelajaran menggunakan model NHT adalah kegiatan penomoran. Kegiatan penomoran yang mampu menghasilkan dampak pengiring bagi siswa, yaitu siswa belajar menerima anggota kelompok yang heterogen dan mungkin saja tidak sesuai dengan yang diinginkan. Pada sesi pengajuan pertanyaan (questioning), siswa dituntut untuk konsentrasi tinggi memperhatikan guru memanggil nomor dan membacakan pertanyaan. Siswa akan menyatukan kepala dan berpikir menemukan jawaban yang tepat bersama kelompoknya. Setiap anggota kelompok mempunyai tugas masing-masing yang harus dipertanggungjawabkan. Pada tahap pemberian jawaban (answering), siswa dengan percaya diri dan tekun menuliskan jawaban dipapan tulis dan siswa lainnya memperhatikan. Langkah terakhir yaitu pemberian penghargaan (reward) untuk kelompok berprestasi. Pemberian 
penghargaan sangat diperlukan dalam setiap pembelajaran, walau hanya sekedar ucapan terimakasih atau dengan tepuk tangan dari seluruh siswa. Dalam hal ini, sportifitas siswa akan tumbuh dan nampak.

\section{PENUTUP}

\section{Simpulan}

Terdapat perbedaan hasil belajar Matematika yang signifikan pada siswa kelas 5 SD Gugus Singoprono 1 dan 3 dalam pembelajaran menggunakan model NHT dan STAD. Simpulan ini didasarkan temuan probabilitas uji ANCOVA 0,002 <0,05, berarti $\mathrm{H}_{0}$ ditolak, $\mathrm{H}_{\mathrm{a}}$ diterima. Signifikansi didukung juga oleh rerata dari dua sampel hasil postes pembelajaran NHT sebesar 81 dan STAD sebesar 74.

\section{Saran}

Berdasarkan hasil penelitian yang dilakukan maka terdapat beberapa saran yang ditujukan. Bagi guru hasil penelitian yang menunjukkan bahwa hasil belajar siswa dengan menggunakan model pembelajaran kooperatif tipe NHT lebih tinggi daripada hasil belajar siswa dengan menggunakan model pembelajaran $S T A D$ pada mata pelajaran matematika, maka guru dapat menerapkan model pembelajaran $N H T$ pada mata pelajaran matematika kelas 5 SD. Bagi Kepala Sekolah, diharapkan dapat mendorong para guru mensosialisasikan keampuhan model pembelajaran kooperatif tipe $N H T$. Bagi peneliti yang lain, hasil penelitian ini dapat digunakan sebagai referensi penelitian berikutnya.

\section{DAFTAR PUSTAKA}

Ardian. 2014. Hasil Belajar Siswa Yang Diperoleh Melalui Model Pembelajaran Cooperative Learning Tipe NHT Dengan STAD Pada Materi Pesawat Sederhana di Kelas V SD Negeri 62 Banda Aceh. Skripsi: Unsyiah.

Azwar, Saifuddin. 2011. Reliabilitas dan Validitas. Yogyakarta: Pustaka Pelajar

Budiyono. 2009. Statistika untuk Penelitian. Surakarta: Sebelas Maret University Press.

Depdiknas. 2006. Lampiran Permendiknas No. 22 Tahun 2006 tentang Standar Isi Satuan Pendidikan Dasar dan Menengah. Jakarta: Depdiknas.

Desi Imanuni. 2013. Perbedaan Hasil Belajar Geografi Siswa Menggunakan Model Pembelajaran Kooperatif Tipe Number Heads Together (NHT) dan Student Team Achievement Division (STAD) Kelas XI IPS SMAN 4 Metro Tahun Pelajaran 2012-2013. Skripsi. Universitas Lampung. Tidak Diterbitkan.

Farida Esty Purwasih. 2014. Perbedaan Hasil Belajar IPA Biologi Menggunakan Pembelajaran Student Team Achivment Division (STAD) Dan Numbered Head Together (NHT) Siswa Kelas VII SMP Negeri 2 Plupuh Sragen Tahun Ajaran 2013/2014. Skripsi. Universitas Muhammadiyah Surakarta. Tidak Diterbitkan.

Gay, L.R 1987. Educational Research. New York: Merrill and Macmillan Pub. and Co.

Huda, M. 2011. Cooperative Learning Metode, teknik, Struktur dan Model Penerapan. Yogyakarta: Pustaka Pelajar.

Ibad, M. 2013. Eksperimentasi Pembelajaran Matematika Metode Kooperatif Tipe Student Teams Achievement Divisions (STAD) dan Metode Kooperatif Tipe Numbered Heads Together (NHT) ditinjau dari Gaya Belajar Siswa. Surakarta: Universitas Sebelas Maret. 
Kuswoyo, Ali. 2009. Keefektifan Model Pembelajaran Kooperatif Tipe STAD dan NHT Terhadap Kemampuan Pemecahan Masalah Matematika Pada Materi Pokok Kubus dan Balok Kelas VIII SMPN 4 Semarang. Skripsi. Universitas Negeri Semarang. Tidak diterbitkan.

Magor, Cervatius, Y. 2010. Perbandingan Penerapan Pembelajaran Kooperatif Model STAD (Student Teams Achievement Divisions) Dan NHT (Numbered Heads Together) untuk Meningkatkan Motivasi dan Hasil Belajar Ekonomi Kelas VII pada Pokok Bahasan Kegiatan Pokok Ekonomi Manusia di SMP Negeri I Singosari. Skripsi. Malang: Universitas Negeri Malang.

Nafisah, R. 2011. Perbedaan Antara Model Pembelajaran Student Teams Achievement Division (STAD) Dengan Model Numbered Heads Together (NHT) Terhadap Keaktifan Peserta Didik Pada Mata Pelajaran Sosiologi Materi Konflik Sosial Kelas XI SMA N 1 Subah. Skripsi. Semarang: UNNES.

Rodi, Hizbi, T., dan Zahara, L. 2011. Pengaruh Pembelajaran Kooperatif Tipe STAD dan NHT terhadap Prestasi Belajar Siswa ditinjau dari Motivasi Berprestasi pada Pokok Bahasan Termodinamika. Tesis. Surakarta: Universitas Sebelas Maret.

Rofiq Setyawan. 2008. Pembelajaran Kooperatif Tipe Number Head Together Pada Pokok Bahasan Opearsi Hitung Campuran Ditinjau dari Motivasi Belajar Siswa. Thesis. Universitas Sebelas Maret Surakarta. Tidak diterbitkan.

Saraswati, I., D. 2010, Penerapan model pembelajaran kooperatif tipe STAD (student Team Achievement Division) untuk meningkatkan motivasi dan hasil belajar siswa pada mata pelajaran manajemen perkantoran (studi pada siswa kelas X Program Keahlian Administrasi Perkantoran di SMK Muhammadiyah 2. Malang: Program Studi Administrasi Perkantoran - Universitas negeri Malang. Tersedia di http://library.um. ac.id/ ptk/index.php?mod=detail\&id=41416

Slavin, R.E. 2009. Cooperative Learning: Teori, Risetdan Praktik.Bandung: Nusa Media.

Slavin, R.E. 2011. Cooperative Learning: Teori, Risetdan Praktik.Bandung: Nusa Media.

Slavin,R.E. 1995. Cooperative Learning: Theory, Research and Practice. Second Edition. Boston: Allyn and Bacon Publisher.

Sugiyono. 2014. Metode Penelitian Pendidikan Pendekatan Kuantitatif, Kualitatif Dan $R \& D$. Bandung: Alfabeta.

Suprijono, A. 2011. Cooperative Learning Teori dan Aplikasi Paikem. Yogyakarta: Pustaka Pelajar.

Trianto. 2009. Mendesain Model Pembelajaran Inovatif-Progresif. Surabaya: Kencana.

Utami, T., A., D., 2011. Eksperimentasi Model Pembelajaran Kooperatif Tipe STAD dan NHT pada pembelajaran Matematika Siswa SMA. Tesis. Surakarta: Universitas Sebelas Maret Surakarta.

Wahyudi. 2012. Pemecahan Masalah Matematika. Salatiga: Widya Sari Press.

Wirani, W. dan Bondan, D. 2012. Komparasi Kemampuan Komunikasi Matematis antara Siswa yang diberi Model Pembelajaran Kooperatif Tipe NHT (Numbered Heads Together) dengan Tipe STAD (Student Teams-Achievement Division) Kelas VII SMPN 5 Depok, Sleman, Yogyakarta. E-Journal Universitas Negeri Yogyakarta. 1 (1): 2.

Yuzianah, Dita. 2011. Efektivitas Pembelajaran Kooperatif Tipe Numbered Heads Together (NHT) dan Student Team Achievement Division (STAD) pada Prestasi Belajar Matematika Ditinjau dari Motivasi Berprestasi. AdMathEdul(1): 1-12. 